\title{
Shallow soil moisture - ground thaw interactions and controls - Part 2: Influences of water and energy fluxes
}

\author{
X. J. Guan ${ }^{1}$, C. Spence ${ }^{1,2}$, and C. J. Westbrook ${ }^{1}$ \\ ${ }^{1}$ Centre for Hydrology, Department of Geography \& Planning, Univ. of Saskatchewan, Saskatoon, Saskatchewan, Canada \\ ${ }^{2}$ Environment Canada, Saskatoon, Saskatchewan, Canada
}

Received: 27 November 2009 - Published in Hydrol. Earth Syst. Sci. Discuss.: 8 January 2010

Revised: 19 May 2010 - Accepted: 17 June 2010 - Published: 29 July 2010

\begin{abstract}
The companion paper (Guan et al., 2010) demonstrated variable interactions and correlations between shallow soil moisture and ground thaw in soil filled areas along a wetness spectrum in a subarctic Canadian Precambrian Shield landscape. From wetter to drier, these included a wetland, peatland and soil filled valley. Herein, water and energy fluxes were examined for these same subarctic study sites to discern the key controlling processes on the found patterns. Results showed the presence of surface water was the key control in variable soil moisture and frost table interactions among sites. At the peatland and wetland sites, accumulated water in depressions and flow paths maintained soil moisture for a longer duration than at the hummock tops. These wet areas were often locations of deepest thaw depth due to the transfer of latent heat accompanying lateral surface runoff. Although the peatland and wetland sites had large inundation extent, modified Péclet numbers indicated the relative influence of external and internal hydrological and energy processes at each site were different. Continuous inflow from an upstream lake into the wetland site caused advective and conductive thermal energies to be of equal importance to ground thaw. The absence of continuous surface flow at the peatland and valley sites led to dominance of conductive thermal energy over advective energy for ground thaw. The results suggest that the modified Péclet number could be a very useful parameter to differentiate landscape components in modeling frost table heterogeneity. The calculated water and energy fluxes, and the modified Péclet number provide quantitative explanations for the shallow soil moisture-ground thaw patterns by linking them with hydrological processes and hillslope storage capacity.
\end{abstract}

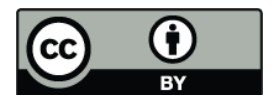

Correspondence to: C. Spence (chris.spence@ec.gc.ca)

\section{Introduction}

Over 50\% of Canada's land surface is underlain with discontinuous or continuous permafrost (Wolfe, 1998). This has profound implications for the hydrology of much of the country because while water can flow in frozen soil, its rate of movement is slowed, and consequentially, lateral and vertical subsurface water fluxes are largely concentrated in the thawed portions above the frost table. Ground thaw has important implications on spatial and temporal soil storage capacities and runoff generation (e.g. Landals and Gill, 1972; Woo and Steer, 1983; Spence and Woo, 2003, 2006; Wright et al., 2009; Guan et al., 2010). For instance, in peatland permafrost landscapes, hydraulic conductivity varies considerably over soil depth due to greater peat decomposition and humification with depth (Quinton and Marsh, 1998, 1999). The water table depth in the peat partly controls the area contributing to runoff. As it drops with ground thaw, it causes the contributing area to decrease due to an increase in subsurface storage capacity (Quinton and Marsh, 1999). Conversely, when the water table position is close to the surface, source areas increase with decreasing flow resistance through the porous organic soils and along hollows (Quinton and Marsh, 1999).

Locations with the most thaw in the spring tend to remain as locations with the most thaw in the summer (Wright et al., 2009). Factors that cause localized differential ground thaw include snow cover and vegetation cover. For example, radiated or advected melt energy from tree trunks can increase snow ablation in the immediate vicinity of the trunks at a faster rate than the surrounding (Faria and Pomeroy, 2000; Pomeroy et al., 2009); this exposes the soil earlier to direct solar energy and consequently, causes soils to thaw earlier. Lichen covered ground tends to have less thaw than mossy cover in the spring due to less efficient water retention properties; though this correlation weakens in the summer as the frost table and saturated zones deepen (Wright et al., 2009).

Published by Copernicus Publications on behalf of the European Geosciences Union. 
Two key controls of frost table depth commonly mentioned in the literature are soil temperature and moisture (e.g. Gray et al., 1988; Kane et al., 2001; Wright et al., 2009). Wright et al. (2009) found wetter years tended to have deeper ground thaw at the inter-annual scale, but a seasonal correlation was not clearly demonstrated. Rouse et al. (1992) noted the opposite correlation at the seasonal scale; a dry season had more ground thaw due to more ground heat flux and thermal diffusivity. Woo and Xia (1996) studied the thermal condition of the active layer at a wetland site and at a drier site and found the wetland experienced less thaw than the drier site due to ice content difference. Carey and Woo (1998a) had similar findings concluding that ice rich locations increase the zero-curtain effect (i.e. latent heat keeps soil at isothermal $\left(\sim 0^{\circ} \mathrm{C}\right)$ for long periods of time, Outcalt et al., 1990) and decrease the rate of ground thaw. Other hydrological and energy forcings can complicate this zero-curtain effect. For example, variable frost table depths have been shown to be strongly tied to spatial soil moisture distribution with wetter locations experiencing deeper ground thaw (Wright et al., 2009; Guan et al., 2010).

Soil moisture has been the focus of many hydrological studies because of its control on surface energy and water balances, vegetation growth and distribution (Grayson et al., 1997; Rodriguez-Iturbe et al., 2007). For long-term water balances, knowledge about the parts of the landscape that are wetter than the average can improve streamflow forecast models (Grayson et al., 1997). Park (1979) found estimating soil moisture values for different land cover types yielded more accurate water balances than using one single, lumped value. Generally, soil moisture closer to the surface is more dynamic than at depth and can be a good indicator of surface runoff responses of soil (Western et al., 2002) and thus, shallow and deep soil moisture should be decoupled in models. For instance, even small changes in the antecedent condition of surface soils can have dramatic non-linear changes in the runoff volume after a storm (James and Roulet, 2007).

Unlike other geographic regions, soils in cold regions are greatly influenced by ground thawing and freezing. Ice in frozen soil increases infiltrating water tortuosity and lowers hydraulic conductivity and infiltration rate (Granger et al., 1984; Black and Miller, 1990). Heat transfer from warmer surface water into the cooler soil has been found to have a strong influence on ground thaw in locations where there is convergence of lateral water flow into frost table depressions (Wright et al., 2009). Similarly, studies in the subarctic and the high arctic have found that surface water flow can enhance ground thaw on footslopes and preferential slope flow routes (Hastings et al., 1989; Hinzman et al., 1993; Carey and Woo, 1998b, 2000). At a subalpine slope in the Yukon Territory, $\sim 9 \%$ of all incoming net radiation was directed to ground thaw in the spring (Shirazi et al., 2009) and there have been documented uses of more than $86 \%$ of the ground heat flux at a peat plateau for melting ground ice (Hayashi et al., 2007). Even though Carey and Woo (1998a) found no strong correlation between ground thaw and ground heat flux and suggested other factors have a more important influence on ground thaw, Hayashi et al. (2007) and Shirazi et al. (2009) noted differential thaw rates due to the thermal conductivity of peat, which is largely dependent on soil water content through its influence on thermal conduction.

Temperate region runoff generation patterns cannot simply be extrapolated to higher latitudes (Carey and Woo, 2001; Quinton and Carey, 2008) because frozen ground and associated hydrological processes influenced by the frost table position complicate these patterns. For instance, aerodynamic and radiant energies have important controls on runoff contribution area at tundra locations (Quinton and Carey, 2008). This close interaction between the energy and hydrological cycles prompted Quinton and Carey (2008) to propose a new hypothesis that better links this coupling. As outlined above, recent studies have shown that the presence of soil water may enhance ground thaw. Understanding the hydrological and energy controls on this relationship is needed to improve storage and runoff parameterization and prediction in cold regions. The question asked in this paper is thus: What are the dominant hydrological and energy controls on the interaction between shallow soil moisture and frost table depth in soil filled areas located in the subarctic Canadian Shield?

\section{Study site}

A detailed description of the study basin and the three study sites (peatland site, valley site and wetland site) is provided in the accompanying paper (Guan et al., 2010). Here, we describe just the climate and hydrology in more detail. The Baker Creek Basin has a continental subarctic climate and air masses predominantly originate in the Arctic Ocean during winter and spring and in the Pacific Ocean during summer and fall (Wolfe, 1998). Climate normals from 19712000 at Environment Canada's climate station, Yellowknife A $\left(62^{\circ} 27^{\prime} \mathrm{N} 114^{\circ} 26^{\prime} \mathrm{W}\right)$ show a mean annual temperature of $-4.6^{\circ} \mathrm{C}$, a January mean of $-26.8^{\circ} \mathrm{C}$ and a July mean of $16.8^{\circ} \mathrm{C}$. The annual precipitation is $281 \mathrm{~mm}$ with $59 \%$ falling as rain. In the summer months, a high evaporation to precipitation ratio is common, and this often results in a negative water balance within the isolated soil filled areas before fall freeze-up (Spence and Rouse, 2002).

The West Bay fault greatly influences Baker Creek's drainage pattern by creating a linked flow pattern in the southeasterly direction (Wight, 1973; Park, 1979). Many areas in the basin are usually isolated and only spill and drain to Baker Creek in the wettest periods (Park, 1979). Park (1979) noted that in areas where isolated local depressions exist, a large volume of annual runoff can be retained. The basin's mean annual runoff ratio is 0.21 (Spence et al., 2010). Some of the key factors controlling the basin's storage capacity and infiltration rates are the Precambrian Shield's extensive bedrock outcrops, short snowmelt duration, and presence of frozen ground (Landals and Gill, 1972). 

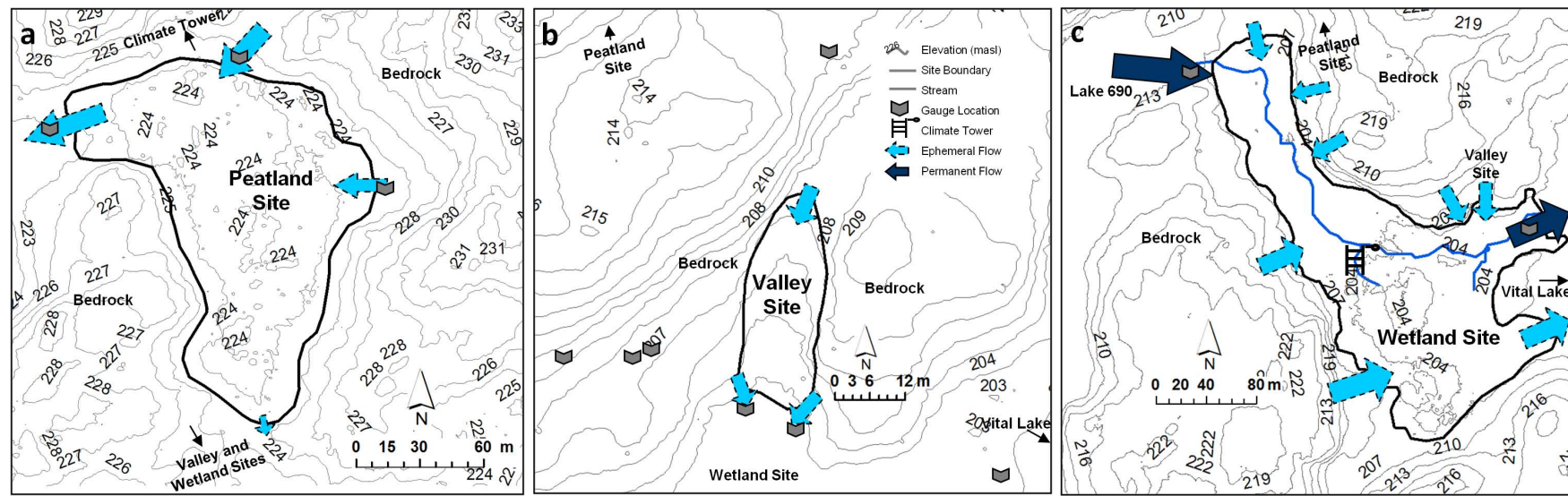

Fig. 1. Main surface flow lines and elevation map of the study sites. The contour interval at the peatland site (a) is $1 \mathrm{~m}, 1 \mathrm{~m}$ at the valley site (b) and $3 \mathrm{~m}$ at the wetland site (c). Elevations are referenced to meters above sea level. Size of arrows is proportional to flow magnitude (e.g. larger arrow indicates relatively greater water flow).

Table 1. Site area, topographic gradient based on $1 \mathrm{~m}$ by $1 \mathrm{~m}$ digital elevation model, shallow soil characteristics (top $0.10 \mathrm{~m}$ ) and saturated hydraulic conductivity $(K)$ at each site. Shallow and deep $K$ are at pipe slot depths described in Sect. 3.1.4.

\begin{tabular}{lccc}
\hline Site & Peatland & Valley & Wetland \\
\hline Area (ha) & 1.4 & 0.04 & 3.3 \\
Gradient (\%) & 3 & 12 & 6 \\
Soil Porosity & 0.85 & 0.83 & 0.80 \\
Soil Bulk Density $\left(\mathrm{kg} \mathrm{m}^{-3}\right)$ & 78 & 113 & 104 \\
Soil Particle Density $\left(\mathrm{kg} \mathrm{m}^{-3}\right)$ & 574 & 644 & 567 \\
Specific Yield & 0.15 & 0.19 & 0.25 \\
$K_{\text {shallow }}\left(\mathrm{m} \mathrm{s}^{-1}\right)$ & $10^{-6}$ & $10^{-5}$ to $10^{-7}$ & $10^{-6}$ to $10^{-7}$ \\
$K_{\text {deep }}\left(\mathrm{m} \mathrm{s}^{-1}\right)$ & $10^{-7}$ to $10^{-8}$ & $10^{-8}$ to $10^{-9}$ & $10^{-6}$ to $10^{-9}$ \\
\hline
\end{tabular}

The hummocky peatland site is hydrologically isolated because it is surrounded by bedrock. It has a number of soil filled bedrock inlets to the east (Fig. 1a). There are two outlets, the key outlet is at the northwest section of the site through a wide, moss and treed covered area. The inlets and outlets flow during snowmelt and after large rain events. The valley site has, in addition to runoff from bare bedrock, a defined soil filled bedrock inlet (Fig. 1b). There are two water eroded outlets toward the bottom of the site with one channel on each side adjacent to the bedrock slopes. Similar to the peatland site, the valley inlets and outlets are only active during snowmelt and following larger rain inputs. The wetland site is situated between two lakes, Lake 690 (unofficial name) and Vital Lake. Water drains from Lake 690, flows through the wetland site (in well defined channels in some areas) and then empties into Vital Lake (Fig. 1c). There was continuous surface inflow and outflow during the 2008 field season. The site is hummocky with many waterlogged hummock hollows that remain permanently wet in the thaw seasons. Physiographic details of the three sites are summarized in Table 1.

\section{Methods}

\subsection{Water fluxes}

At each site, the following water fluxes were measured or calculated to elucidate the measured soil moisture and frost table patterns found by Guan et al. (2010):

$$
P+\mathrm{M}+\mathrm{I}-Q-\mathrm{ET}=\Delta S
$$

where $P$ is precipitation, $\mathrm{M}$ is melt, $\mathrm{I}$ is inflow, $\mathrm{Q}$ is discharge, ET is evapotranspiration, and $\Delta S$ is change in storage (all units are $\mathrm{mm} \mathrm{d}^{-1}$ ). One limitation of any water budget is that the accuracy of $\Delta S$ is dependent on the accuracy of the other fluxes and accuracies are thus listed, where available. Fluxes were assumed uniform over space.

\subsubsection{Meteorological measurements}

Meteorological data were collected on the bedrock above the peatland site and in the wetland site. The peatland station was installed on bare bedrock with sparse tree cover and the wetland station was at a partly saturated area with deciduous shrubs in its immediate surrounding. The peatland 
station measured air temperature, $T\left({ }^{\circ} \mathrm{C}\right)$ and relative humidity, RH (\%) at two heights, wind speed, $u\left(\mathrm{~m} \mathrm{~s}^{-1}\right)$, wind direction, $u_{\text {dir }}$ (degree), net radiation, $Q^{*}\left(\mathrm{~W} \mathrm{~m}^{-2}\right)$, and rainfall, $P(\mathrm{~mm})$. The instruments were connected to a Campbell Scientific CR23X datalogger. $T$ and RH at two heights, $u, Q^{*}$ and $P$ were also measured at the wetland site with a Campbell Scientific CR1000 datalogger. Data were scanned every minute and averaged at half-hour intervals.

\subsubsection{Snow survey and snow cover interpolation}

Snow surveys were completed at each of the three study sites following the methods described in Pomeroy and Gray (1995) and Woo (1997). Mean snow water equivalent, SWE $(\mathrm{mm}, \pm 15 \%)$ was calculated for each transect using:

$\mathrm{SWE}=\frac{\rho_{\mathrm{s}} d}{\rho_{\mathrm{W}}}$

where $\rho_{s}$ is snow density $\left(\mathrm{kg} \mathrm{m}^{-3}\right), d$ is mean snow depth $(\mathrm{mm})$ and $\rho_{\mathrm{W}}\left(1000 \mathrm{~kg} \mathrm{~m}^{-3}\right)$ is water density. All individual SWE samples were averaged over site to obtain an overall mean SWE for each site. After the snow survey, to account for any newly fallen snow, one snowboard was set up by each ablation line (Sect. 3.1.3) and monitored daily.

\subsubsection{Melt}

An ablation line was set up at each of the three sites to monitor daily ablation rate, $M_{\mathrm{a}}( \pm 25 \%)$ following the approaches described in Heron and Woo (1978). Each line consisted of 10 points spaced $\sim 0.2 \mathrm{~m}$ apart, and at the time height to snow measurements were made, surface (top $16 \mathrm{~mm}$ ) snow density samples were also collected. The daily depth of melt rate $\left(M, \mathrm{~mm} \mathrm{day}^{-1}\right)$ at each soil filled zone was calculated as:

$M=(\underbrace{(\Delta \bar{z}) \frac{\rho_{\mathrm{s}}}{\rho_{\mathrm{w}}}}_{M_{\mathrm{a}}}-s_{\mathrm{b}}) a_{\mathrm{s}}$

where $\Delta \bar{z}$ is mean snow depletion between two consecutive days $\left(\mathrm{mm} \mathrm{day}^{-1}\right)$ and $s_{\mathrm{b}}$ is sublimation loss $\left(\mathrm{mm} \mathrm{day}^{-1}\right)$. The $s_{\mathrm{b}}$ was calculated with the latent heat available for vapourization using latent heat flux data from the peatland meteorological station. The rates were weighted to the fraction of area with snow cover ( $a_{\mathrm{s}}$, unitless) at each of the sites estimated from daily site photos.

\subsubsection{Inflow}

Channelized surface inflow $\left(I_{\mathrm{S}}\right)$ was measured where possible with a SonTek FlowTracker acoustic doppler velocimeter that was accurate to $1 \%$, i.e. $\pm 2.5 \mathrm{~mm} \mathrm{~s}^{-1}$. Channelized inflow into the peatland site was measured every one to two days from two bedrock runoff locations, and at the valley and wetland sites, from one location at each site (Fig. 1). The inflow to the wetland site from Lake 690 was thoroughly documented during the study period. A Solinst Levelogger was placed in Lake 690 to record the lake level every half-hour. These data were used to find a stage-discharge relationship at the lake outlet. The lake water level was also manually measured with a survey level approximately once a week during the study period and opportunistically at other times to adjust the Levelogger readings if necessary. Half-hourly readings from a Solinst Barologger installed at the wetland site were used to compensate Levelogger readings for fluctuations in barometric pressure. Spence and Woo (2006) noted accuracy of rating curves derived this way as $20 \%$.

Field data were used to model flow from soil covered and bare bedrock into the sites. For bedrock with soil cover, data from the two peatland inlets and one valley inlet were used. Values were sometimes overestimated since measurements were done only when there was enough water to fully submerge the velocimeter. For bare bedrock upland runoff, three sheet metal weirs comparable to those used by Spence and Woo (2002) (Fig. 1b) were installed in fall 2007. Spence and Woo (2002) noted these weirs can measure runoff to an accuracy within $7 \%$. The recorded runoff volumes were converted into depths based on the bedrock contributing area to the weirs. The boundaries of the contribution area were visually delineated in the summer based on best judgment and then surveyed with a total station. To calculate total lateral inflow from the surrounding bedrock upland (both bare and soil covered bedrock), the contribution areas to each site were delineated with the watershed tool in the ArcGIS hydrology spatial analyst toolbox using data from a $1 \mathrm{~m}$ resolution digital elevation model. After the total contribution area was delineated, a classified Quickbird satellite image and observations were used to categorize all bedrock side slopes as either bare or soil covered to model flow from each category separately. To prevent bare bedrock that flows into soil covered bedrock from being counted twice (i.e. once as bare bedrock runoff and then again for soil covered bedrock), all bare areas contributing to soil covered bedrock were subtracted from bare bedrock runoff calculations. Runoff from the bedrock side slopes $\left(R_{\mathrm{bss}}\right)$ was calculated as:

$R_{\mathrm{bss}}=\frac{\left(R_{\mathrm{b}} a_{\mathrm{b}}\right)+\left(R_{\mathrm{sc}} a_{\mathrm{sc}}\right)}{a_{\mathrm{bss}}}$

where $R$ is runoff generated (mm), $a$ is area $\left(\mathrm{m}^{2}\right)$ over which runoff is generated, subscripts bss, $b$, and sc are bedrock side slope, bare bedrock and soil covered bedrock, respectively. To convert $R_{\mathrm{bss}}$ from depth of runoff per unit area of bedrock side slope into depth over each of the study sites $\left(I_{\mathrm{bss}}\right)$, the following equation was used:

$I_{\mathrm{bss}}=\frac{R_{\mathrm{bss}} a_{\mathrm{bss}}}{a_{\mathrm{v}}}$

where $a_{\mathrm{v}}$ is the site area. At sites where lake inflow was measured (e.g. the wetland site), $I_{\mathrm{bss}}$ was added to it to get total $I_{\mathrm{s}}$ into the soil filled site. 
Piezometer nests were installed at each site to monitor groundwater flux. At the peatland site, there were three wells and five piezometer nests consisting of slots at shallow $(0.20 \mathrm{~m})$ and deep $(0.50 \mathrm{~m})$ depths. The valley site had four wells and five piezometer nests, of which two of the five nests had a third piezometer. At this site, slot depths were variable due to loose rocks in the substrate that made installation of pipes to a constant depth difficult. The shallow slots were all $\sim 0.20 \mathrm{~m}$, the medium slots averaged $\sim 0.35 \mathrm{~m}$ and the two deep slots were $0.50 \mathrm{~m}$ and $0.55 \mathrm{~m}$. At the wetland site, there were five wells and 11 piezometer nests that were installed at shallow depths $(0.20 \mathrm{~m})$ and deep depths $(0.50 \mathrm{~m})$. Three additional piezometers were installed along the stream to determine if the stream was losing or gaining water. Hydraulic heads were measured on average every three days for all wells and piezometers. At the peatland and valley sites, extensive surrounding bedrock prevented subsurface flow from entering the sites. At the wetland site, subsurface inflow, $I_{\mathrm{sb}}$ (mm) was calculated as:

$I_{\mathrm{sb}}=\frac{K\left(h_{1}-h_{2}\right)}{\Delta l} A_{\mathrm{c}}$

where $K$ is hydraulic conductivity $\left(\mathrm{m} \mathrm{d}^{-1}\right),\left(h_{1}-h_{2}\right) / \Delta l$ is hydraulic gradient with water table level difference $\left(h_{1}\right.$ and $h_{2}$ ) over distance between the piezometer nests installed in a soil filled valley located north and upslope of the wetland $(\Delta l)\left(\mathrm{m} \mathrm{m}^{-1}\right)$ and $A_{\mathrm{c}}$ is cross-sectional area $\left(\mathrm{m}^{2}\right)$. Our best estimate of $I_{\mathrm{sb}}$ accuracy was $30 \%$. Saturated hydraulic conductivity $(K)$ was measured in the piezometers installed at each site and calculated with the Luthin approach (1966), a common method used in the arctic (e.g. Woo and DiCenzo, 1989; Quinton et al., 2000; Hodgson and Young, 2001). Shallow and deeper hydraulic conductivities are listed in Table $1 . I_{\mathrm{sb}}$ was then converted to depth $(\mathrm{mm})$ by dividing the total site area.

\subsubsection{Discharge}

The surface discharge $\left(Q_{\mathrm{s}}\right)$ at each site was measured using similar techniques as with inflow at the main outlet of each site (Fig. 1). However, due to the nature of each site's outlet the measured values did not always capture the full extent of outflow. Thus, $Q_{\mathrm{s}}$ was sometime computed as the difference between calculated $\Delta S$ and observed storage change $\left(\Delta S_{0}\right)$ since this was deemed to be more accurate on days with missing or suspect observed data. The authors recognize that this approach embeds the residual error into the estimated flux. However, it was still advantageous to have a continuous dataset with approximated values from an accepted approach. The number of days with estimated $Q_{\mathrm{s}}$ for the peatland, valley and wetland were 18,3 and 54 , respectively. The subsurface outflow, $Q_{\mathrm{sb}}$ was measured with the same approaches as described for $I_{\mathrm{sb}}$.

\subsubsection{Evapotranspiration}

Evapotranspiration (ET) was calculated using the PenmanMonteith equation as described in Shuttleworth (1993):

$\mathrm{ET}=\frac{1}{\lambda}\left(\frac{\Delta\left(Q^{*}-Q_{\mathrm{g}}\right)+\frac{\rho_{\mathrm{a}} c_{\mathrm{p}} D}{r_{\mathrm{a}}}}{\Delta+\gamma\left(1+\frac{r_{\mathrm{c}}}{r_{\mathrm{a}}}\right)}\right)$

where $\lambda$ is latent heat of vapourization of water $\left(\mathrm{MJ} \mathrm{kg}^{-1}\right), \Delta$ is slope of saturated vapour pressure $\left(\mathrm{kPa}^{\circ} \mathrm{C}^{-1}\right), Q^{*}$ is net radiation $\left(\mathrm{MJ} \mathrm{m}^{-2} \mathrm{~d}^{-1}\right)$ measured at the wetland site with a Kipp \& Zonen NR-LITE net radiometer, $Q_{\mathrm{g}}$ is ground heat flux $\left(\mathrm{MJ} \mathrm{m}^{-2} \mathrm{~d}^{-1}\right), \rho_{\mathrm{a}}$ is moist air density $\left(\mathrm{kg} \mathrm{m}^{-3}\right)$ calculated with the ideal gas law, $c_{\mathrm{p}}$ is specific heat of moist air $\left(0.001013 \mathrm{MJ} \mathrm{kg}^{-1}{ }^{\circ} \mathrm{C}^{-1}\right), D$ is vapour pressure deficit $(\mathrm{kPa}), r_{\mathrm{a}}$ is aerodynamic resistance $\left(\mathrm{d} \mathrm{m}^{1}\right), \gamma$ is psychrometric constant $\left(\mathrm{k} \mathrm{Pa}^{\circ} \mathrm{C}^{-1}\right)$, and $r_{\mathrm{c}}$ is canopy resistance $\left(\mathrm{d} \mathrm{m}^{-1}\right)$. The $Q_{\mathrm{g}}$ was calculated with the Fourier heat flow equation with soil temperature measured with $\mathrm{ECH}_{2} \mathrm{O}$ TE sensors. The $r_{\mathrm{a}}\left(\mathrm{d} \mathrm{m}^{-1}\right)$ was calculated following methods outlined in Shuttleworth (1993), Brutsaert (1975) and Monteith (1981). The $r_{\mathrm{c}}$ was calculated with a revised version of the Jarvis (1976) and Verserghy et al. (1993) expression using environmental conductance functions of incoming solar radiation and $D$ (Lafleur and Schreader, 1994). The resultant mean $r_{\mathrm{c}}$ was $1.1 \times 10^{-2} \mathrm{dm}^{-1}$ for the peatland vascular cover, $2.5 \times 10^{-4} \mathrm{~d} \mathrm{~m}^{-1}$ for the peatland lichen cover, $2.8 \times 10^{-3} \mathrm{~d} \mathrm{~m}^{-1}$ at the valley site and $1.1 \times 10^{-3} \mathrm{~d} \mathrm{~m}^{-1}$ at the wetland site. The Penman-Monteith ET method has been shown to underestimate by $\sim 20 \%$ in other subarctic Shield studies (Lafleur, 1992; Spence, 2000).

Parts of the peatland and wetland were flooded from the snowmelt period to the end of the field season. To find the potential ET (PET) for these locations, the Penman Combination equation (1948) was used:

$\mathrm{PET}=\frac{\Delta k_{\mathrm{c}} Q^{*}+\gamma E_{\mathrm{A}}}{\Delta+\gamma}$

where $k_{\mathrm{c}}$ is a unit converter from $\mathrm{MJ} \mathrm{m}^{-2} \mathrm{~d}^{-1}$ to $\mathrm{mm} \mathrm{d}^{-1}$ $\left(k_{\mathrm{c}}=0.408\right), E_{\mathrm{A}}$ is mass transfer $\left(\mathrm{m} \mathrm{d}^{-1}\right)$ from a Dalton-type equation (1802):

$E_{\mathrm{A}}=f(u) D$

where $f(u)$ is the wind function (i.e. vapour transfer function) in $\mathrm{mm} \mathrm{k} \mathrm{Pa}^{-1} \mathrm{~d}^{-1}$. Here, the Penman derived $f(u)$ was used:

$f(u)=2.63\left(1+0.537 u_{2}\right)$

where $u_{2}$ is wind speed at a reference height of $2 \mathrm{~m}\left(\mathrm{~m} \mathrm{~s}^{-1}\right)$. $u$ measured at a height of $3.4 \mathrm{~m}$ from the wetland station was standardized to the reference height of $2 \mathrm{~m}$ with the following 
equation:

$u_{2}=u_{m} \frac{\ln \left(z_{2}-0.67 h_{\mathrm{c}}\right)-\ln \left(0.123 h_{\mathrm{c}}\right)}{\ln \left(z_{\mathrm{m}}-0.67 h_{\mathrm{c}}\right)-\ln \left(0.123 h_{\mathrm{c}}\right)}$

$u_{\mathrm{m}}$ is measured wind speed $\left(\mathrm{m} \mathrm{s}^{-1}\right), z_{2}$ is the desired wind speed reference height $(m), h_{\mathrm{c}}$ is height of canopy cover $(\mathrm{m})$, and $z_{\mathrm{m}}$ is actual instrument height $(\mathrm{m})$.

The daily mean evapotranspiration loss was prorated between ET and PET based on fraction of non-flooded and flooded areas. These fractions were determined from ponded water records noted during soil moisture and frost table surveys (Guan et al., 2010). There was surface ponding at the peatland and wetland sites during the study period and thus both potential (flooded area) and soil ET were calculated at these sites.

\subsubsection{Observed storage change}

Observed change in storage, $\Delta S_{\mathrm{o}}$ was calculated using the method described in Spence and Woo (2006):

$$
\Delta S_{\mathrm{o}}=\Delta S_{\mathrm{u}}+\Delta S_{\mathrm{s}}=\Delta \theta\left[z(t)-z_{\mathrm{W}}(t)\right]+s_{y}\left[z_{\mathrm{W}}(t)-z_{\mathrm{W}}(t-1)\right]
$$

where $\Delta S_{\mathrm{u}}$ and $\Delta S_{\mathrm{s}}$ are unsaturated and saturated storage change (mm), respectively. For $\Delta S_{\mathrm{u}}, \Delta \theta$ is the daily change in soil moisture content as calculated from half-hourly soil moisture data recorded with $\mathrm{ECH}_{2} \mathrm{O}-\mathrm{TE}$ sensors that were connected to Em50 analogue dataloggers. These were located at each of the sites at two depths, $z$ (i.e. just below surface and $0.25 \mathrm{~m}$ below ground surface). Two stations per site were equipped with these sensors; one station set up approximately in the middle and the other toward the outer site boundary. The sensors were calibrated with site specific soil samples at the end of the field season. $\left[z(t)-z_{\mathrm{W}}(t)\right]$ is total unsaturated soil thickness where $z(\mathrm{~mm})$ is based on total thaw depth or total depth to clay due to the limited movement in fine grained soil, whichever is reached first. The peatland site has unsubstantial clay content, the depth to clay at the valley site was averaged to $0.20 \mathrm{~m}$ and at the wetland site, $0.40 \mathrm{~m}$. The water table depths $\left(z_{\mathrm{w}}(t), \mathrm{mm}\right)$ were measured in fully slotted wells in the form of rigid PVC pipes capped at the bottom. At each site, two wells (one at edge of site and one in middle of site) had continuous half-hourly water table level measurements from Solinst Leveloggers. When the soil column was saturated, all the soil pores were filled with water (the space occupied by air bubbles was assumed to be small and ignored here) and unsaturated storage would be zero. Specific yields used to compute $\Delta S_{\mathrm{s}}$ for the sites are listed in Table 1. Specific yield was determined in the laboratory by saturating soil samples enforced with mesh and soaked in water for $24 \mathrm{~h}$ and then weighed. The samples were left on a grid stand for $24 \mathrm{~h}$ of gravitational drainage and reweighed to determine the water loss. Porosity, bulk density and particle density were also tested in the laboratory using site specific soil samples and the values are listed in Table 1.
The term $\left[z_{\mathrm{W}}(t)-z_{\mathrm{W}}(t-1)\right]$ represents daily change in thickness of saturated zone $(\mathrm{mm})$. The observed storage change had an expected accuracy of 25\% (Spence and Woo, 2006).

\subsection{Ground heat flux into the soil}

Total ground heat flux into the soil $\left(Q_{\mathrm{gf}}\right)$ from heat conduction from the soil surface $\left(Q_{\mathrm{gs}}\right)$ and surface water ponding $\left(Q_{\mathrm{gp}}\right)$ along with heat advection from flowing water $\left(Q_{\mathrm{gw}}\right)$ were calculated by modifying the method described in Woo and Xia (1996):

$Q_{\mathrm{gf}}=\underbrace{\left.K_{\mathrm{T}} \frac{d T}{d z}\right|_{\text {surface }}}_{\text {conduction }\left(Q_{\mathrm{gs}}, Q_{\mathrm{gp}}\right)}+\underbrace{c_{\mathrm{w}} \Delta T \frac{d F}{d t}}_{\text {advection }\left(Q_{\mathrm{gw}}\right)}$

where all the above $Q_{\mathrm{gf}}$ terms are in $\mathrm{MJ} \mathrm{m}^{-2} \mathrm{~d}^{-1}, K_{\mathrm{T}}$ is thermal conductivity calculated as the function of the fraction of mineral soil, organic soil, ice, water and air multiplied by each medium's thermal conductivity (de Vries, 1963; Farouki, 1981), dT/dz is temperature gradient from surface soil or ponded water to the thawing front. The soil temperature was continuously recorded by the $\mathrm{ECH}_{2} \mathrm{O}$-TE sensors, ponded water temperature was recorded with Onset HOBO StowAway Tidbit temperature loggers, and a thawing front temperature of $0^{\circ} \mathrm{C}$ was used. $c_{\mathrm{w}}$ is volumetric heat capacity of water, $\Delta T$ is temperature difference between flowing water and the frozen ground. Snowmelt runoff temperature was measured with a Solinst Levelogger at the soil covered bedrock inlet to the valley site, and was assumed to represent all bedrock runoff temperatures. Lake 690 water temperature was also recorded with the aforementioned Levelogger used for lake storage. $d F / d t$ is flow rate $\left(\mathrm{m}^{3} \mathrm{~d}^{-1}\right)$. A limitation was that any error for this volume from the water budget was carried forward. The total inflow water was divided over the dynamic area affected by moving surface water. Not all inflowing water was infiltrated into the ground and some energy would be lost to the atmosphere (e.g. through evapotranspiration) and therefore it should be recognized that potential $Q_{\text {gw }}$ was being calculated. However as results will show, when large heat content was available, there remained ample amounts of energy to be transferred into the frozen ground.

Similar to ET and PET, the total $Q_{\mathrm{gs}}, Q_{\mathrm{gp}}$ and $Q_{\mathrm{gw}}$ energies available to the frozen ground needed to be partitioned based on the fraction of non-flooded and flooded areas (ponded or flowing) at the sites over time. This was not needed at the valley site since it was flooded only briefly during the snowmelt runoff period.

\subsection{Modified Péclet number for northern wetlands}

The Péclet number $(P e)$ concept has been adopted in many disciplines, and used to quantify landscape spacing of firstorder valleys (e.g. Perron et al., 2008) to hillslope subsurface flow (e.g. Lyon and Troch, 2007). Its wide usage is 
because it can translate often qualitative findings to dimensionless quantitative numbers that can be used in computer models. The $P e$ equation as described in Stüwe (2007) is:

$P e=\frac{u_{\mathrm{a}} l}{k_{\mathrm{d}}}$

where $u_{\mathrm{a}}$ is advection rate $\left(\mathrm{m} \mathrm{s}^{-1}\right), 1(\mathrm{~m})$ is the $u_{\mathrm{a}}$ characteristic length scale and $k_{\mathrm{d}}$ is diffusivity $\left(\mathrm{m}^{2} \mathrm{~s}^{-1}\right)$. When $P e$ equals 1 , both advection and diffusion are equally important processes, when $P e \gg 1$, the advective process dominates and when $P e \ll 1$, the diffusive process is the dominant factor. Kane et al. (2001) used $P e$ to calculate the fraction of heat energy transfer from convection versus conduction in their examination of non-conductive heat transfer in frozen ground. The Pe equation used in Kane et al. (2001) does not account for advected latent heat. Even with this limitation from the original version of the $P e$, its underlying concept that relates the relative influence of multiple heat transfers can be very useful in ground thaw studies. The $P e$ in this paper was modified ( $\mathrm{mPe}$ ) to create a dimensionless number to represent the relative influence of total advective energy versus total conductive energy at northern soil filled areas:

$\mathrm{m} P e=\frac{\sum Q_{\mathrm{gw}}}{\sum Q_{\mathrm{gs}}+\sum Q_{\mathrm{gp}}}$

The $\mathrm{mPe}$ will discern the dominant ground heat source(s) thawing the frozen ground at each site. While the variables used to calculate each of the $Q_{\mathrm{g}}$ terms in Eq. (13) do not explicitly match those in Eq. (14), Eq. (15) is consistent with the underlying concept of calculating heat transfer ratios. It is recognized that errors from water budget terms and energy budgets terms carried these error through to the $\mathrm{mPe}$. Based on the accuracy of rating curves as discussed in Sect. 3.1.4, a sensitivity analysis of $\pm 20 \% d F / d t$ in $Q_{\mathrm{gw}}$ gives a best estimate of $\sim 20 \%$ accuracy for $\mathrm{mPe}$.

\section{Results}

\subsection{Hydrological fluxes}

\subsubsection{Snowmelt}

The end of winter SWE (12 April 2008) were $93 \mathrm{~mm}$ at the peatland site, $117 \mathrm{~mm}$ at the valley site and $61 \mathrm{~mm}$ at the wetland site. Snowpack depth measurements were conservative as the mean daily air temperatures from 9-13 April were above $0{ }^{\circ} \mathrm{C}$ and some snowmelt and runoff was observed upon arrival to the study site. However, mean daily air temperature dropped below $0^{\circ} \mathrm{C}$ on 14 April and did not warm up to $0^{\circ} \mathrm{C}$ again until 27 April (Fig. 2). The snow ripened again on 27 April at all three sites. Most of the snow melted by 4 May at the valley site, contributing $45 \mathrm{~mm}$ of water equivalent to the site (Fig. 3). At the peatland site, there was an observed increase in snow-free areas with snowmelt on 27 April, occurring first mainly on high hummocks. The

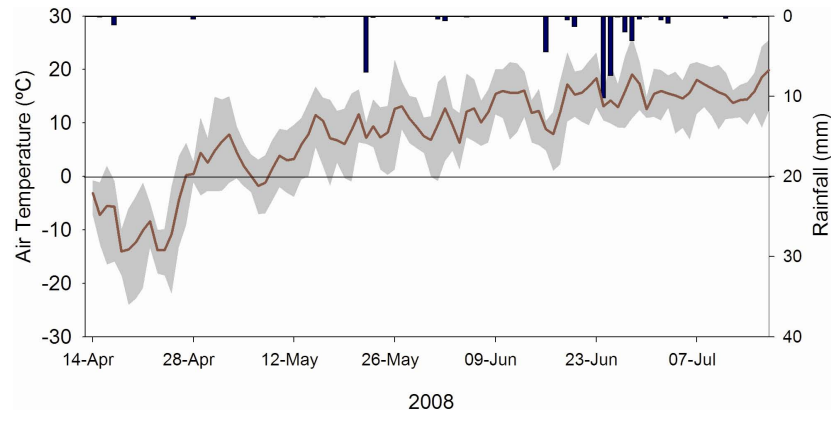

Fig. 2. Mean daily air temperature (range is shown in grey) and total daily rainfall measured at the wetland climate tower.

majority of snow at the peatland site disappeared by 3 May. Exceptions were some hollows in the middle of the site and along the outer boundary in the dense conifer stands. Total snowmelt into the peatland was $73 \mathrm{~mm}$. Outflow from Lake 690 through the winter of 2007/2008 created aufeis $0.32 \mathrm{~m}$ thick in the wetland. Assuming an ice density of $920 \mathrm{~kg} \mathrm{~m}^{-3}$, this ice layer amounted to an additional $294 \mathrm{~mm}$ of water storage at the wetland site prior to snowmelt. Snow and ice at the wetland site melted first along a surface stream conveying water from Lake 690 across the site (Fig. 4). By 30 April, snow at the wetland ablation line thawed to the ice layer. Much of the snow and ice cover melted by 13 May, however, patches remained until 21 May. These patches were located in dense shrub and conifer stands, except for locations with surface flow. Total snow and ice melt input to the wetland was $185 \mathrm{~mm}$.

\subsubsection{Rainfall}

All three sites were within $1 \mathrm{~km}$ from the wetland climate station and thus, rainfall at the peatland and valley sites was expected to be the same as at the wetland site. A total of $42 \mathrm{~mm}$ of rainfall fell from 14 April to 17 July (Fig. 2). The rainfall in May, June and July (full month) were 7, 31 and $15 \mathrm{~mm}$, respectively. The 1971-2000 climate normals from the Environment Canada Yellowknife A station are $19 \mathrm{~mm}$, $27 \mathrm{~mm}$ and $35 \mathrm{~mm}$ for the months of May, June and July, respectively, which indicates May to July 2008 was relatively dry, i.e. $65 \%$ of normal.

\subsubsection{Inflow}

Bedrock runoff was observed on 12 April and 13 April during a warm spell. When the mean daily air temperature dropped back to below $0{ }^{\circ} \mathrm{C}$ on 14 April, bedrock runoff ceased until 27 April. After that, it flowed at a mean daily rate of $14 \mathrm{~mm} \mathrm{day}^{-1}$ (Fig. 3; i.e. a component of the total surface volume) when the mean daily temperature reached $>0.2^{\circ} \mathrm{C}$ (Fig. 2). The highest mean daily rate was measured on 30 April with $19 \mathrm{~mm} \mathrm{day}^{-1}$ of flow. For the bare bedrock weirs, the last date with flow through all three weirs was 


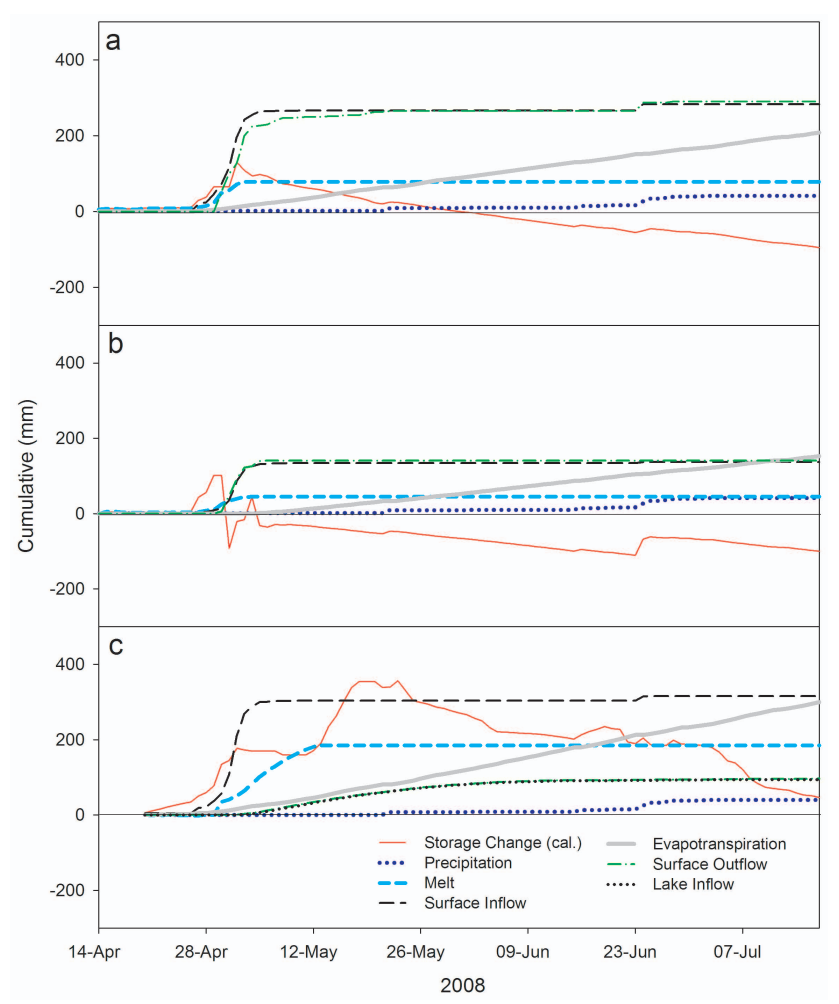

Fig. 3. Cumulative water budget for the (a) peatland, (b) valley, and (c) wetland sites (mm per unit area) for 14 April to 17 July 2008. For display purposes, surface inflow and outflow values are $1 / 10$ th of actual for the valley site (i.e. $\sim 137 \mathrm{~mm}$ of cumulative inflow shown in graph is representing the actual $\sim 1370 \mathrm{~mm}$; total surface outflow was $34 \mathrm{~mm}$ higher than surface inflow). Surface outflow and lake inflow are 1/100th of actual for the wetland site (total surface flow was $196 \mathrm{~mm}$ higher than Lake 690 inflow).

3 May. Over approximately 2 weeks in early spring, $266 \mathrm{~mm}$, $1338 \mathrm{~mm}$ and $298 \mathrm{~mm}$ of bedrock runoff was measured at the peatland, valley and wetland sites, respectively. The valley site was a flow through system during snowmelt and most of the recorded surface inflow only channeled across the ground surface. The 22 May rainfall filled many bedrock micro-depressions and initiated bedrock runoff at some locations, however, the flow depth and volume were inconsequential. Rain on 24-25 June led to widespread bedrock runoff at all three sites. A mean daily inflow rate of $12 \mathrm{~mm}$ and $0.4 \mathrm{~mm}$ were measured from the three bedrock weirs on 24 and 25 June, respectively. Using these rates, bedrock coverage, and site area to model the two day total $I_{\mathrm{bss}}$ showed $17 \mathrm{~mm}$ of input to the peatland site, $34 \mathrm{~mm}$ into the valley site and $12 \mathrm{~mm}$ into the wetland site. One assumption of the average measured bedrock runoff rates was that they were representative of all bedrock outcrops, independent of site.
Inflow from Lake 690 was recorded starting on 20 April once a lake level pressure transducer was installed. It is assumed there was continuous inflow from Lake 690 during the winter because of the icing across the wetland site. The mean daily discharge from Lake 690 during the study period was $3.5 \times 10^{3} \mathrm{~m}^{3}$ day $^{-1}$ or $106 \mathrm{~mm} \mathrm{day}^{-1}$ (Figs. $3 \mathrm{c}$ and 5). The mean was skewed by the high flow that occurred in May $\left(8.4 \times 10^{3} \mathrm{~m}^{3} \mathrm{day}^{-1} ; 257 \mathrm{~mm} \mathrm{day}^{-1}\right)$ compared to June $\left(1.4 \times 10^{3} \mathrm{~m}^{3} \mathrm{day}^{-1} ; 43 \mathrm{~mm} \mathrm{day}^{-1}\right)$ and July $\left(2.2 \times 10^{2} \mathrm{~m}^{3}\right.$ day $^{-1} ; 7 \mathrm{~mm}$ day $\left.^{-1}\right)$. Lake 690 discharge decreased drastically when the lake level dropped below its natural outlet dam level in mid-June and a large decrease in discharge was observed from 6 to 14 June. The cumulative surface water input at the site leveled out when this threshold was reached (Fig. 5). Most of the discharge water flowed through holes in the debris dam. At the wetland site, there was thawed ground along the surface flow pathways. The peatland site had approximately two orders of magnitude less cumulative lateral surface water input than the wetland site whereas the valley site had approximately one order of magnitude less lateral surface water input than the peatland site (Figs. 3 and 5).

Subsurface inflow at the wetland site was negligible relative to the large quantity of surface inflow. The mean daily rate was $0.005 \mathrm{~mm} \mathrm{day}^{-1}$. Although a range of $K$ was recorded at the site (Table 1), a sensitivity analysis suggested changes in $K$ had little impact on the estimated subsurface inflow. At the peatland site, the extensive bedrock surrounding the site prevented significant subsurface inflow into the site. The available measurements from the valley site when the pipes were not ice jammed, or had measurable water table depth revealed subsurface flow to be low. Its estimated maximum subsurface flow rate was $0.04 \mathrm{~mm} \mathrm{day}^{-1}$ since the water table position was mostly within the deeper fine mineral soil which has a $K$ of $10^{-8}$ to $10^{-9} \mathrm{~m} \mathrm{~s}^{-1}$.

\subsubsection{Discharge}

Surface discharge from the wetland site was observed on 12 April and continued on and off even when bedrock runoff briefly terminated between 14 and 27 April. At the wetland site, there were two outlets bisected by a bedrock island; both drained into Vital Lake. Surface discharge from the wetland site was observed throughout the study period while the peatland and valley sites had surface discharge only in the snowmelt period and from some rainfall events (e.g. 24 June, Fig. 2). Over the study period, $\sim 290 \mathrm{~mm}, \sim 1400 \mathrm{~mm}$, $\sim 9630 \mathrm{~mm}$ of $Q_{\text {s }}$ was measured from the peatland site, valley site, and wetland site, respectively.

Subsurface outflow from the wetland amounted to $0.001 \mathrm{~mm} \mathrm{day}^{-1}$ and flow out of the valley site was expected to be similar to the subsurface input (maximum $0.04 \mathrm{~mm}$ day $^{-1}$ ). At the peatland site, subsurface flow was low due to low hydraulic gradient (averaging $1.8 \mathrm{~mm} \mathrm{~m}^{-1}$ ). 


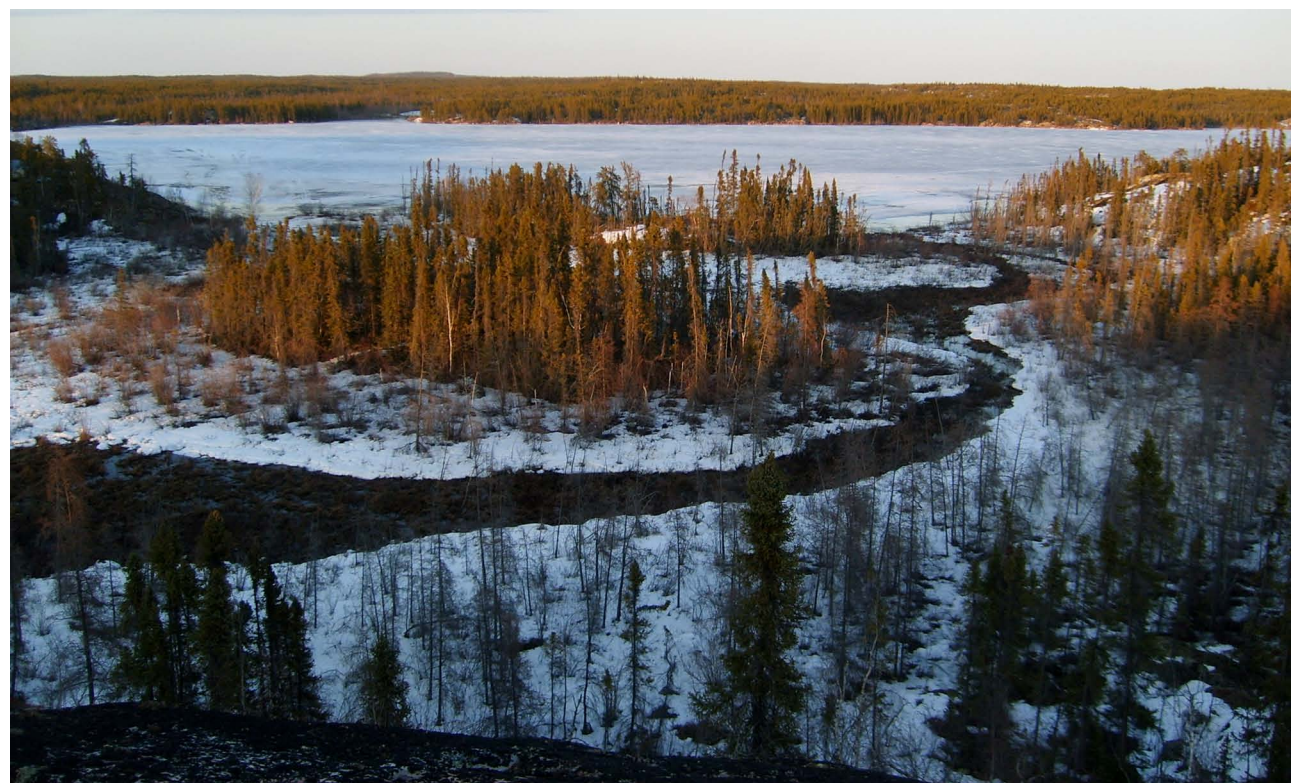

Fig. 4. The wetland site on 6 May 2008 during the snowmelt period. Snow and ice melted at a faster rate along surface runoff routes, while much of the remaining snow covered areas were outside of flow pathways. Photo was taken facing east with Vital Lake (ice covered) in the background.

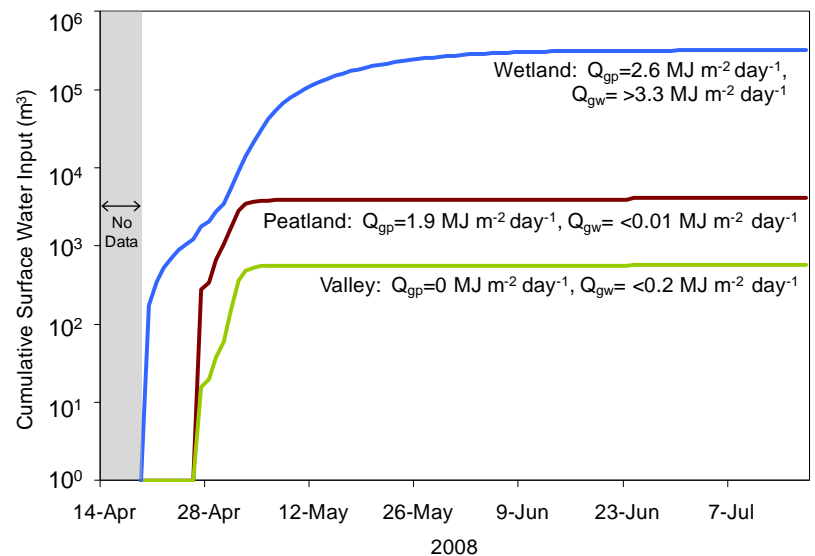

Fig. 5. Surface water input to the sites (snowmelt runoff at all sites and additional lake input at wetland site) and potential amount of energy from water available for ground thaw at each site. No Lake 690 data were available before 20 April 2008. $Q_{\mathrm{gp}}$ is conductive heat energy from ponded water and $Q_{\mathrm{gw}}$ is advective heat energy from surface water flow. The wetland $Q_{\mathrm{gw}}$ of $3.3 \mathrm{MJ} \mathrm{m}^{-2}$ day $^{-1}$ is derived from dividing the overall site daily mean of $1.09 \times 10^{5} \mathrm{MJ}$ day $^{-1}$ evenly over the 3.3 ha site. However, the actual fraction of area influenced by surface water was much smaller. For example, $35 \%$ of the 3.3 ha site had flowing or standing water on 6 June, resulting in $\sim 9.5 \mathrm{MJ} \mathrm{m}^{-2}$ day $^{-1}$ of potential $Q_{\mathrm{gw}}$ available for transfer into the frozen ground. See Eq. (13) for details on energy calculations.

\subsubsection{Evapotranspiration}

The peatland site had an overall daily ET rate of $2.5 \mathrm{~mm} \mathrm{day}^{-1}$, with a total loss of $208 \mathrm{~mm}$ over the study period (Fig. 3a). Surface ponding at the wetland site was more widespread and was maintained longer than at the peatland site. The more extensive ponding and different vegetation cover led to more evaporative loss at the wetland site; the daily mean was $3.2 \mathrm{~mm} \mathrm{day}^{-1}$ for a total loss of $302 \mathrm{~mm}$ over the study period (Fig. 3c). The valley site was the driest of the sites as well as the site with the highest surface and aerodynamic resistances. The valley lost water to the atmosphere at a daily mean rate of $2.1 \mathrm{~mm} \mathrm{day}^{-1}$ and had a total loss of $153 \mathrm{~mm}$ (Fig. 3b).

\subsubsection{Storage change}

Change in storage differed across the three sites. The peatland and valley sites experienced a storage deficit as outputs exceeded inputs by the end of the study. At the peatland site, there was an overall storage loss of $95 \mathrm{~mm}$, while there was a storage loss of $100 \mathrm{~mm}$ at the valley site (Fig. 3a and $b$ ). In contrast, the wetland site had an overall storage gain of $44 \mathrm{~mm}$ (Fig. 3c) due to the large inputs of snowmelt, bedrock runoff and Lake 690 water during early spring. Although there was continuous surface inflow into the site from Lake 690, a decline in storage occurred coincident with declining Lake 690 inflow in mid-June onward. 


\subsection{Ground heat fluxes}

\subsubsection{Conductive and advective ground heat into the soil}

Positive values of $Q_{\mathrm{gs}}$ began on 30 April at the peatland site, 5 May at the valley site and 17 May at the wetland site. At the peatland site, daily $Q_{\mathrm{gs}}$ averaged $1.1 \mathrm{MJ} \mathrm{m}^{-2}$ day $^{-1}$ for a sum of $83 \mathrm{MJ} \mathrm{m}^{-2}$ over the study period. The valley site had a mean daily rate of $0.5 \mathrm{MJ} \mathrm{m}^{-2} \mathrm{day}^{-1}$ and a total of $36 \mathrm{MJ} \mathrm{m}^{-2}$ of $Q_{\mathrm{gs}}$ over the study period. The daily average $Q_{\mathrm{gs}}$ at the wetland site was $2.0 \mathrm{MJ} \mathrm{m}^{-2} \mathrm{day}^{-1}$, and the total over the study period was $113 \mathrm{MJ} \mathrm{m}^{-2}$.

The $Q_{\mathrm{gp}}$ was only computed for dates when there was surface ponding (see Guan et al., 2010, for detailed description of surface ponding patterns). From 9 May to 9 July, the fraction of area flooded at the peatland site dropped from 0.38 to 0.06. At the wetland site, the first recorded fraction of flooded area was also 0.38, but that was on 28 May and it then decreased to 0.22 by 8 July. Flooded areas at the wetland site included both stagnant ponding and surface flow. It was difficult to distinguish the two categories of flooding at low flow locations, so all areas with surface water were grouped into one category. Instead of calculating an absolute energy flux for this flooding, a range of values (low $Q_{\mathrm{gp}}$ value to high $Q_{\mathrm{gw}}$ ) were calculated for the wetland site. The valley site experienced only a brief period of surface ponding during snowmelt so $Q_{\mathrm{gp}}$ was negligible. Flooded locations in the peatland site transferred $147 \mathrm{MJ} \mathrm{m}^{-2}$ of $Q_{\mathrm{gp}}$ to the soil at a mean daily rate of $1.9 \mathrm{MJ} \mathrm{m}^{-2}$ day $^{-1}$ (Fig. 5). At the wetland site, $158 \mathrm{MJ} \mathrm{m}^{-2}$ of energy was transferred from surface ponding at a mean daily rate of $2.6 \mathrm{MJ} \mathrm{m}^{-2}$ day $^{-1}$ (Fig. 5).

Thermal conduction transfers heat to the thawing front, but non-conductive heat transfer (e.g. from infiltration and percolation) can also contribute large quantities of heat to the thawing front (Kane et al., 2001). The $Q_{\mathrm{gw}}$ calculation for snowmelt runoff started on 27 April when runoff across the bedrock surface was observed. The mean values were $0.005 \mathrm{MJ} \mathrm{m}^{-2} \mathrm{day}^{-1}$ at the peatland site, $0.2 \mathrm{MJ} \mathrm{m}^{-2}$ day $^{-1}$ at the valley site and $0.003 \mathrm{MJ} \mathrm{m}^{-2} \mathrm{day}^{-1}$ at the wetland. In contrast, the Lake 690 water input during the study period carried a daily mean of $1.09 \times 10^{5} \mathrm{MJ}$ day $^{-1}$ of $Q_{\mathrm{gw}}$ into the wetland site, or $3.3 \mathrm{MJ} \mathrm{m}^{2} \mathrm{day}^{-1}$ if this flowing water was over the entire site (Fig. 5). Since the areal extent of flowing water was never $100 \%$ over the site, the available $Q_{\mathrm{gw}}$ was $>3.3 \mathrm{MJ} \mathrm{m}^{-2} \mathrm{day}^{-1}$. Recall from above that only the fraction of the wetland with flowing water had $Q_{\mathrm{gw}}$ available and the available energy was concentrated to only this area. For instance, on 6 June, $35 \%$ of the 3.3 ha site was flooded and if it is considered that this areal fraction had flowing water, a maximum (accounting for some loss to the atmosphere) of $9.5 \mathrm{MJ} \mathrm{m}^{-2} \mathrm{day}^{-1}$ of $Q_{\mathrm{gw}}$ was available for transfer into the frozen ground. $Q_{\mathrm{gw}}$ was also calculated for rain water, but was negligible due to the low rain temperature and input during the study period.

\subsubsection{Modified Péclet numbers for northern wetlands}

If it is assumed that inflowing water flowed across the entirety of each site, and the advective energies are uniform over the study site areas, the peatland site would have a $\mathrm{mPe}$ of 0.0004 and the valley site a $\mathrm{mPe}$ of 0.09 (per unit area). If the topological controls influencing the peatland and valley sites (i.e. isolated and surrounded by bedrock) were the same at the wetland site, the wetland $\mathrm{mPe}$ would have been in the same order of magnitude as at the peatland at 0.0002 . Because of the wetland's important connection to Lake 690, its $\mathrm{mPe}$ was instead 1.1. This value was derived by applying the Lake $690 Q_{\mathrm{gw}}$ over the entire wetland site. The $\mathrm{dF} / \mathrm{dt}$ term in the $Q_{\mathrm{gw}}$ equation accounts for total energy carried by the inflowing water. To conceptualize, a one-to-one comparison for conductive against advective forcings that could be directed into one grid permitted comparison of these values among sites - it was simplest to visualize in the same grid how much conductive energy is available versus the amount of advective energy is available. However, as noted above, flooding at the wetland site was more spatially variable than this and never reached 100\%. As described in Sect. 4.2.1, the amount of $Q_{\mathrm{gw}}$ per unit area increases as flooded area grows smaller, thus, it is more accurate to say the wetland $\mathrm{m} P e$ value was always $>1.1$. This $\mathrm{mPe}$ was several orders of magnitude larger than for the other two sites.

\section{Discussion}

A combination of a reduction in lateral water input, low precipitation to evapotranspiration ratio $(0.20$ at the peatland site, 0.27 at the valley site and 0.13 at the wetland site) and ground thaw led to the overall drying trend in soil condition observed over the study period. However, the intra- and intersite variability in soil moisture and ground thaw patterns described in Guan et al. (2010) were largely a function of lateral water exchange. At the intra-site scale, the absence of surface water accumulation at the valley site led to very different soil moisture and thaw patterns from those observed at the peatland and wetland sites. At the inter-site scale, results show many of the deep thaw locations were found in grids with either ponding or higher soil moisture content. The ponded and flowing surface water thus were the key differences among the sites since the inflowing water can contribute large quantities of latent heat energy to the frozen ground for thaw. Site topology was a critical control on how much water was received (Guan et al., 2010). For example, the wetland site was a flow-through system because it was situated between two lakes (690 and Vital). An aufeis layer developed from winter flooding by Lake 690 at this site led to a prolonged snowmelt period; continuous lake water inflow sustained the site wetness in the thaw months.

The surface inflow strongly influenced the spatial patterns of frost table depth and thaw documented at the wetland site (Guan et al., 2010). Here, the ice rich soil required a large 
quantity of latent ground heat to thaw it. The large amount of potential advective heat transferred into the ground from the lake water thawed soil along parts of the flow routes to depths $\geq 1 \mathrm{~m}$ before the wetland was fully snow-free. Although much of this surface inflow to the wetland site was drained to Vital Lake, the water had frequent contact with the soil as it flowed in and out of the soil toward Vital Lake. Some of this energy was lost to the atmosphere (e.g. through evapotranspiration), but due to the large heat content available, there remained ample energy for transfer into melting the frozen ground. Carey and Woo (1998a) noted from their high arctic study at Resolute Bay, Canada that locations with more ice rich conditions in the winter months would thaw at a slower rate than locations that were not ice rich. These results show that when surface water is plenty, it can enhance ground thaw enough to efficiently thaw even ice rich soil. Other key differences between this subarctic and Carey and Woo's high arctic site may be the number of thawing degree-days. In comparison, the peatland and valley sites thawed at a slower rate than the wetland site in the spring due to the absence of advective ground heat from lake water as dictated by individual site topology. The peatland and valley sites did not have continuous surface lateral inflow. Runoff per unit area into the peatland and valley sites was only $\sim 3 \%$ and $\sim 14 \%$ of that received by the wetland site, respectively. The meltwater runoff did not add a significant amount of advective energy into the peatland and valley soil due to the similarity in temperature between the cool meltwater and cool soil during the freshet. However, at the peatland site, the extensive surface ponding in the hollows as controlled by the gentle topography and hummock-hollow typology kept the peat saturated for longer and increased the thermal conductivity of this organic soil. This enhanced local ground thaw, creating high spatial heterogeneity in the frost table position. These results contrast with those of Mackay (1981) and Quinton and Marsh (1995). Their work with mineral hummocks and peaty hollows shows peat decreases downward penetration of heat, which leads to less thaw in hollows (Mackay, 1981; Quinton and Marsh, 1995). The soil type and hollow ponding were some of the causes of the difference observed at the Baker Creek sites compared to the sites studied by Mackay (1981) and Quinton and Marsh (1995).

Presented thus far is a discussion of how conductive and advective heat energies regulated soil thawing along flow routes and ponded areas. However, radiative energy $\left(Q_{\mathrm{gg}}\right)$ was important to ground thaw at locations without surface flow or ponding. Locations only influenced by radiative energy were found to commonly have more homogeneous thaw depths and slower thaw rates. For instance, at the valley site, negligible amounts of $Q_{\mathrm{gp}}$ and $Q_{\mathrm{gw}}$ were available due to limited surface water storage. Thus, the drier site condition mostly explained the site's slower thaw rate. Differences in $Q_{\mathrm{gs}}$ among the sites were primarily due to higher soil thermal conductivity in the increasingly wetter soils in the peatland and wetland. Furthermore, the conifers and bedrock at the valley site decreased net radiation received at the ground surface, which further decreased the radiative energy available to the soil. Soil wetting from small rain events during the field season often only rewetted surface soils. Overall rain influence on ground heat flux was limited and this was comparable to the small amount of heat from rain water found by studies in Resolute Bay, Nunavut and the subarctic Yukon Territory (Woo and Xia, 1996; Carey and Woo, 2000).

The wetland $\mathrm{mPe}$ was four orders of magnitude higher than the peatland $\mathrm{mPe}$ due to more predominant external versus internal controlling processes on the energy budget. The energy from the lake water accelerated localized ground thaw rates at the wetland while the peatland thaw rate was relatively more gradual. The advective and conductive energies at the wetland site were of approximate equal importance whereas the conductive energy at the other two sites was of more importance to the sites' energy budget. The valley had little surface ponding (i.e. low $Q_{\mathrm{gp}}$ ) and had an $\mathrm{mPe}$ that was two orders of magnitude larger than the peatland. The size of the valley was smaller than the other two sites and so the energy from the inflow runoff volume amounted to more energy per unit area. One limitation of the $\mathrm{mPe}$ however was many variables in the ground heat flux terms were assumed to be uniform across each site due to the spatial resolution of data. Results from this study support the energy-based paradigm for runoff generation proposed by Quinton and Carey (2008).

\section{Conclusions}

Results showed that the relative topology, topography and typology influences at each site dictated the energy and water flux controls on shallow soil moisture and ground thaw. Overall, soil moisture, on the one hand, influences the thermal conductivity and heat energy available for ground thaw. On the other hand, deeper ground thaw increases water storage capacity. Soil moisture and frost table patterns are largely controlled by surface water because the water keeps soil moisture high and in the right conditions permit the transfer of substantial quantities of latent heat to the ground that result in more soil thaw than at sites lacking substantial surface ponding or flow. These energy influences can be quantified with the $\mathrm{mPe}$ and could be used in the future to categorize soil filled areas and incorporated in hydrological model parameterization. The results provide explanations for the shallow soil moisture-ground thaw correlations documented in Guan et al. (2010) by linking them with hydrological processes related to water budget nuances among the three sites. Using similar methods to study other cold regions (e.g. high arctic), and incorporating groundwater flow and deeper soil moisture into the calculation of $\mathrm{mPe}$ in future research are recommended. Such studies would complement our findings and provide a strong base for upscaling, parameterizing and incorporating the results into cold region hydrological models to predict subsurface water storage. 


\section{Appendix}

\section{List of symbols}

\begin{tabular}{|c|c|}
\hline$a_{\mathrm{b}}$ & Area of Bare Bedrock $\left[\mathrm{m}^{2}\right]$ \\
\hline$a_{\mathrm{bss}}$ & Area of Bedrock Side Slopes $\left[\mathrm{m}^{2}\right]$ \\
\hline$A_{\mathrm{c}}$ & Cross-Sectional Area $\left[\mathrm{m}^{2}\right]$ \\
\hline$a_{\mathrm{s}}$ & Fraction of Area with Snow Cover [unitless] \\
\hline$a_{\mathrm{sc}}$ & Area of Soil Covered Bedrock $\left[\mathrm{m}^{2}\right]$ \\
\hline$a_{\mathrm{v}}$ & Area of Site $\left[\mathrm{m}^{2}\right]$ \\
\hline$c_{\mathrm{p}}$ & Specific Heat of Moist Air $\left[\mathrm{MJ} \mathrm{kg}^{-1{ }^{\circ}} \mathrm{C}^{-1}\right.$ ] \\
\hline$d$ & Snow Depth $[\mathrm{m}]$ \\
\hline$D$ & Vapour Pressure Deficit $[\mathrm{kPa}$ or $\mathrm{mb}]$ \\
\hline$d F / d t$ & Flow Rate $\left[\mathrm{m}^{3} \mathrm{~d}^{-1}\right]$ \\
\hline$d T / d z$ & Temperature Gradient $\left[{ }^{\circ} \mathrm{Cm}^{-1}\right]$ \\
\hline$E_{\mathrm{A}}$ & Mass Transfer $\left[\mathrm{m} \mathrm{d}^{-1}\right]$ \\
\hline ET & Evapotranspiration $\left[\mathrm{mm} \mathrm{day}^{-1}\right]$ \\
\hline$f(u)$ & Wind Function $\left[\mathrm{mm} \mathrm{k} \mathrm{Pa}^{-1} \mathrm{~d}^{-1}\right]$ \\
\hline$h$ & Water Table Depth [m] \\
\hline$h_{\mathrm{c}}$ & Height of Canopy Cover [m] \\
\hline$I$ & Inflow $\left[\mathrm{mm} \mathrm{day}^{-1}\right]$ \\
\hline$I_{\mathrm{bss}}$ & $\begin{array}{l}\text { Runoff from Bedrock Side Slope over } \\
\text { Study Site Area [mm] }\end{array}$ \\
\hline$I_{\mathrm{S}}$ & Surface Inflow $\left[\mathrm{mm}\right.$ day $\left.^{-1}\right]$ \\
\hline$I_{\mathrm{sb}}$ & Subsurface Inflow $\left[\mathrm{mm} \mathrm{day}^{-1}\right]$ \\
\hline$K$ & Saturated Hydraulic Conductivity [ $\mathrm{m} \mathrm{s}^{-1}$ ] \\
\hline$k_{\mathrm{c}}$ & Unit Converter from $\mathrm{MJ} \mathrm{m}^{-2} \mathrm{~d}^{-1}$ to $\mathrm{mm} \mathrm{d}^{-1}$ \\
\hline$k_{\mathrm{d}}$ & Diffusivity $\left[\mathrm{m}^{2} \mathrm{~s}^{-1}\right]$ \\
\hline$K_{\mathrm{T}}$ & Thermal Conductivity $\left[\mathrm{W} \mathrm{m}^{-1}{ }^{\circ} \mathrm{C}^{-1}\right.$ ] \\
\hline$l$ & $u_{\mathrm{a}}$ Characteristic Length Scale $[\mathrm{m}]$ \\
\hline$\Delta l$ & Horizontal Distance Change [m] \\
\hline$M$ & Melt $\left[\mathrm{mm} \mathrm{day}^{-1}\right]$ \\
\hline$M_{\mathrm{a}}$ & Ablation Rate $\left[\mathrm{mm} \mathrm{day}^{-1}\right]$ \\
\hline $\mathrm{mPe}$ & Modified Péclet number [unitless] \\
\hline$P$ & Precipitation $\left[\mathrm{mm} \mathrm{day}^{-1}\right]$ \\
\hline $\mathrm{Pe}$ & Péclet Number [unitless] \\
\hline PET & Potential Evapotranspiration [mm day $\left.{ }^{-1}\right]$ \\
\hline$Q$ & Discharge $\left[\mathrm{mm} \mathrm{day}^{-1}\right]$ \\
\hline$Q^{*}$ & Net Radiation $\left[\mathrm{W} \mathrm{m}^{-2}\right]$ \\
\hline$Q_{\mathrm{g}}$ & Ground Heat Flux $\left[\mathrm{MJ} \mathrm{m}^{-2} \mathrm{~d}^{-1}\right]$ \\
\hline$Q_{\mathrm{gf}}$ & $\begin{array}{l}\text { Total Ground Heat Flux into Frozen Ground } \\
{\left[\mathrm{MJ} \mathrm{m}^{-2} \mathrm{~d}^{-1}\right]}\end{array}$ \\
\hline$Q_{\mathrm{gp}}$ & $\begin{array}{l}\text { Heat Conduction from Surface Water Ponding } \\
{\left[\mathrm{MJ} \mathrm{m}^{-2} \mathrm{~d}^{-1}\right]}\end{array}$ \\
\hline$Q_{\mathrm{gs}}$ & $\begin{array}{l}\text { Heat Conduction from Surface Soil } \\
{\left[\mathrm{MJ} \mathrm{m}^{-2} \mathrm{~d}^{-1}\right]}\end{array}$ \\
\hline$Q_{\mathrm{gw}}$ & $\begin{array}{l}\text { Heat Advection from Flowing Water } \\
{\left[\mathrm{MJ} \mathrm{m}^{-2} \mathrm{~d}^{-1}\right]}\end{array}$ \\
\hline$Q_{\mathrm{s}}$ & Surface Discharge $[\mathrm{mm}]$ \\
\hline$Q_{\mathrm{sb}}$ & Subsurface Discharge $[\mathrm{mm}]$ \\
\hline$r_{\mathrm{a}}$ & Aerodynamic Resistance $\left[\mathrm{d} \mathrm{m}^{-1}\right]$ \\
\hline$R_{\mathrm{b}}$ & Runoff from Bare Bedrock [mm] \\
\hline$R_{\mathrm{bss}}$ & Runoff from Bedrock Side Slopes [mm] \\
\hline
\end{tabular}

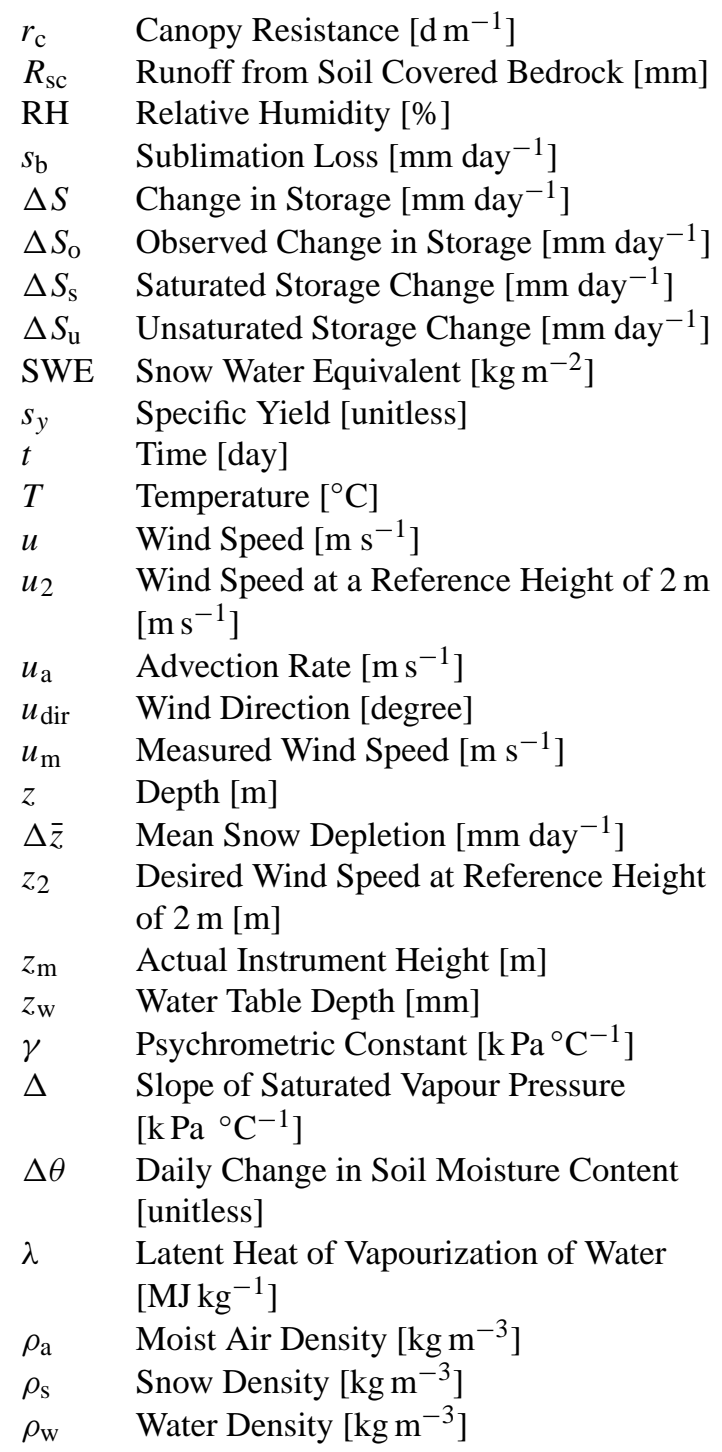

Acknowledgements. We thank Ross Phillips, Newell Hedstrom, Dave and Rhonda Phillips, Erin Shaw and Dave Fox for their field assistance. We also thank Bob Reid, Water Survey of Canada staff (Northwest Territories and Nunavut branch), Julie Friddell and Mike Solohub for their logistical support. Thank you also to John Pomeroy and Bing Si for their suggestions along the way and three anonymous reviewers for their constructive comments. We also gratefully acknowledge financial support provided by Environment Canada, International Polar Year, the Canadian Foundation for Climate and Atmospheric Sciences via the Improved Processes and Parameterisation for Prediction in Cold Regions programme, Association of Canadian Universities for Northern Studies' Garfield Weston Award for Northern Research, and Indian and Northern Affairs Canada's Northern Scientific Training Program.

Edited by: M. Weiler 


\section{References}

Black, P. B. and Miller, R. D.: Hydraulic conductivity and unfrozen water content of air-free frozen soil, Water Resour. Res., 26, 323329, 1990.

Brutsaert, W.: Comments on surface roughness parameters and the height of dense vegetation, J. Meteorol. Soc. Jpn., 53, 96-97, 1975.

Carey, S. K. and Woo, M.-k.: A case study of active layer thaw and its controlling factors, in: Proceedings of the Seventh International Conference on Permafrost, edited by: Lewkowicz, A. G. and Allard, M., Yellowknife, Canada, 23-27 June 1998, 127132, 1998a.

Carey, S. K. and Woo, M.-k.: Snowmelt hydrology of two subarctic slopes, Southern Yukon, Canada, Nord. Hydrol., 29, 331-346, 1998 b.

Carey, S. K. and Woo, M.-k.: Within-slope variability of ground heat flux, subarctic Yukon, Phys. Geogr., 21, 407-417, 2000.

Carey, S. K. and Woo, M.-K.: Slope runoff processes and flow generation in a subarctic, subalpine catchment, J. Hydrol., 253, 110119, 2001.

Dalton, J.: Experimental essays on the constitution of mixed gases: on the force of steam or vapour from water or other liquids in different temperatures, both in a Torricelli vacuum and in air; on evaporation; and on expansion of gases by heat, Manchester Lit. Phil. Soc. Mem., 5, 536-602, 1802.

de Vries, D. A.: Thermal properties of soils, in: Physics of Plant Environment, North-Holland Publishing Co., Amsterdam, 210235, 1963.

Faria, D. A., Pomeroy, J. W., and Essery, R. L. H.: Effect of covariance between ablation and snow water equivalent on depletion of snow-covered area in a forest, Hydrol. Process., 14, 2683-2695, 2000.

Farouki, O. T.: Thermal properties of soils, CRREL Monograph No. 81-1, U.S. Army Cold Regions Research and Engineering Laboratory, Hanover, New Hampshire, 136 pp., 1981.

Granger, R. J., Gray, D. M. and Dyck, G. E.: Snowmelt infiltration to frozen prairie soils, Can. J. Earth Sci., 21, 669-677, 1984.

Gray, J. T., Pilon, J., and Poitevin, J.: A method to estimate active-layer thickness on the basis of correlations between terrain and climatic parameters as measured in northern Quebec, Can. Geotech. J., 25, 607-616, 1988.

Grayson, R. B., Western, A. W., Chiew, F. H. S., and Blöschl, G.: Preferred states in spatial soil moisture patterns: Local and nonlocal controls, Water Resour. Res., 33, 2897-2908, 1997.

Guan, X. J., Westbrook, C. J., and Spence, C.: Shallow soil moisture - ground thaw interactions and controls - Part 1: Spatiotemporal patterns and correlations over a subarctic landscape, Hydrol. Earth Syst. Sci., 14, 1375-1386, 2010, http://www.hydrol-earth-syst-sci.net/14/1375/2010/.

Hastings, S. J., Luchessa, S. A., Oechel, W. C., and Tenhunen, J. D.: Standing biomass and foothills of the Phillip Smith Mountains, Alaska, Holarctic Ecol., 12, 304-311, 1989.

Hayashi, M., Goeller, N., Quinton, W. L., and Wright, N.: A simple heat-conduction method for simulating the frost-table depth in hydrological models, Hydrol. Process., 21, 2610-2622, 2007.

Heron, R. and Woo, M.-k.: Snowmelt computation for a High Arctic site, in: Proceedings of the 35th Eastern Snow Conference, Hanover, New Hampshire, 162-172, 1978.
Hinzman, L. D., Kane, D. L., and Everett, K. R.: Hillslope hydrology in an Arctic setting, in: Proceedings of the Sixth International Conference on Permafrost, Beijing, China, 5-9 July 1993, 257-271, 1993.

Hodgson, R. and Young, K. L.: Preferential groundwater flow through a sorted net landscape, arctic Canada, Earth Surf. Proc. Land., 26, 319-328, 2001.

James, A. L. and Roulet, N. T.: Investigating hydrologic connectivity and its association with threshold change in runoff response in a temperate forested watershed, Hydrol. Process., 21, 33913408, 2007.

Jarvis, P. G.: The interpretation of the variations in leaf water potential and stomatal conductance found in canopies in the field, Philos. T. Roy. Soc. B, 273, 593-610, 1976.

Kane, D. L., Hinkel, K. M., Goering, D. J., Hinzman, L. D., and Outcalt, S. I.: Non-conductive heat transfer associated with frozen soils, Global Planet. Change, 29, 275-292, 2001.

Lafleur, P. M.: Energy balance and evapotranspiration from a subarctic forest, Agr. Forest Meteorol., 58, 163-175, 1992.

Lafleur, P. M. and Schreader, C. P.: Water loss from the floor of a subarctic forest, Arctic Alpine Res., 26, 152-158, 1994.

Landals, A. L. and Gill, D.: Differences in volume of surface runoff during the snowmelt period: Yellowknife, Northwest Territories, in: Proceedings of the International Symposia on the Role of Snow and Ice in Hydrology, IAHS, Banff, Alberta, September 1972, 107, 927-942, 1972.

Luthin, J. N.: Drainage Engineering, Wiley, New York, USA, 250 pp., 1966.

Lyon, S. W. and Troch, P. A.: Hillslope subsurface flow similarity: Real-world tests of the hillslope Péclet number, Water Resour. Res., 43, W07450, doi:10.1029/2006WR005323, 2007.

Mackay, J. R.: Active layer slope movement in a continuous permafrost environment, Garry Island, Northwest Territories, Canada, Can. J. Earth Sci., 18, 1666-1680, 1981.

Monteith, J. L.: Evaporation and surface temperature, Q. J. Roy. Meteor. Soc., 107, 1-27, 1981.

Outcalt, S.I., Nelson, F.E. and Hinkel, K.M.: The zero-curtain effect: heat and mass transfer across an isothermal region in freezing soil, Water Resour. Res., 26, 1509-1516, 1990.

Park, J. O.: Vegetation patterns and moisture availability in the Baker Creek Basin, near Yellowknife, NWT, M.Sc. thesis, University of Alberta, Edmonton, 228 pp., 1979.

Penman, H. L.: Natural evaporation from open water, bare soil, and grass, P. R. Soc. Lond. A Mat., 193, 120-145, 1948.

Perron, J. T., Dietrich, W. E., and Kirchner, J. W.: Controls on the spacing of first-order valleys, J. Geophys. Res., 113, F04016, doi:10.1029/2007JF000977, 2008.

Pomeroy, J. W. and Gray, D. M.: Snow Accumulation, Relocation and Management, National Hydrology Research Institute Science Report No. 7, Environment Canada: Saskatoon, 144 pp., 1995.

Pomeroy, J. W., Marks, D., Link, T., Ellis, C., Hardy, J., Rowlands, A., and Granger R.: The impact of coniferous forest temperature on incoming longwave radiation to melting snow, Hydrol. Process., 23, 2513-2525, doi:10.1002/hyp.7325, 2009.

Quinton, W. L. and Carey, S. K.: Towards an energy-based runoff generation theory for tundra landscapes, Hydrol. Process., 22, 4649-4653, 2008. 
Quinton, W. L., Gray, D. M., and Marsh, P.: Subsurface drainage from hummock-covered hillslopes in the arctic-tundra, J. Hydrol., 237, 113-125, 2000.

Quinton, W. L. and Marsh, P.: Subsurface runoff from tundra hillslopes in the continuous permafrost zone, in: Report and Proceedings of the International GEWEX Workshop on ColdSeason/Region Hydrometeorology, Banff, Alberta, 22-26 May 1995, 51-55, 1995.

Quinton, W. L. and Marsh, P.: The influence of mineral earth hummocks on subsurface drainage in the continuous permafrost zone, Permafrost Periglac., 9, 213-228, 1998.

Quinton, W. L. and Marsh, P.: A conceptual framework for runoff generation in a permafrost environment, Hydrol. Process., 12, 2563-2591, 1999.

Rodriguez-Iturbe, I., D’Odorico, P., Laio, F., Ridolfi, L., and Tamea, S.: Challenges in humid land ecohydrology: Interactions of water table and unsaturated zone with climate, soil, and vegetation, Water Resour. Res., 43, W09301, doi:10.1029/2007WR006073, 2007.

Rouse, W. R., Carlson, D. W. and Werck, E. J.: Impacts of summer warming on the energy and water balance of wetland tundra, Climatic Change, 22, 305-326, 1992.

Shirazi, T., Allen, D. M., Quinton, W. L. and Pomeroy, J. W.: Estimating soil thaw energy in sub-Alpine tundra at the hillslope scale, Wolf Creek, Yukon Territory, Canada, Hydrol. Res., 40, 1-18, 2009.

Shuttleworth, W. J.: Evaporation, in: Handbook of Hydrology, McGraw-Hill, New York, edited by: Maidment, D. R., 4.1-4.53, 1993.

Spence, C.: The effect of storage on runoff from a headwater subarctic shield basin, Arctic, 53, 237-247, 2000.

Spence, C., Guan, X. J., Phillips, R., Hedstrom, N., Granger, R., and Reid, B.: Storage dynamics and streamflow in a catchment with a variable contributing area, Hydrol. Process., 24, 2209-2221, doi:10.1002/hyp.7492, 2010.

Spence, C. and Rouse, W.R.: The energy budget of Canadian Shield subarctic terrain and its impact on hillslope hydrological processes, J. Hydrometeorol., 3, 208-218, 2002.
Spence, C. and Woo, M.-k.: Hydrology of subarctic Canadian Shield: bedrock upland, J. Hydrol., 262, 111-127, 2002.

Spence, C. and Woo, M.-k.: Hydrology of subarctic Canadian shield: soil-filled valleys, J. Hydrol., 279, 151-166, 2003.

Spence, C. and Woo, M.-k.: Hydrology of subarctic Canadian Shield: heterogeneous headwater basins, J. Hydrol., 317, 138154, 2006.

Stüwe, K.: Geodynamics of the Lithosphere, 2edn., Springer, Heidelberg, 493 pp., 2007.

Verseghy, D. L., McFarlane, N.A. and Lazare, M., A Canadian land surface scheme for GCMs, II. Vegetation model and coupled runs, Int. J. Climatol., 13, 347-370, 1993.

Western, A. W., Grayson, R. B., and Blöschl, G.: Scaling of soil moisture: A hydrologic perspective, Annu. Rev. Earth Pl. Sc., 30, 149-180, 2002.

Wight, J. B.: Aspects of evaporation and evapotranspiration in the water balance of Baker Creek Basin, near Yellowknife, NWT, M.Sc. thesis, University of Alberta, Edmonton, 329 pp., 1973.

Wolfe, S. A.: Living with Frozen Ground: A Field Guide to Permafrost in Yellowknife, Miscellaneous Report 64, Geological Survey of Canada, Northwest Territories, 71 pp., 1998.

Woo, M.-k.: A guide for ground based measurement of arctic snow cover, Canadian Snow Data CD, Meteorological Service of Canada, Downsview, Ontario, 30 pp., 1997.

Woo, M.-k. and DiCenzo, P. D.: Hydrology of small tributary streams in a subarctic wetland, Can. J. Earth Sci., 26, 1557-1556, 1989.

Woo, M.-k. and Steer, P.: Slope hydrology as influenced by thawing of the active layer, Resolute, N. W.T., Can. J. Earth Sci., 20, 978986, 1983.

Woo, M.-k. and Xia, Z.: Effects of hydrology on the thermal conditions of the active layer, Nord. Hydrol., 27, 129-142, 1996.

Wright, N., Hayashi, M., and Quinton, W. L.: Spatial and temporal variations in active layer thawing and their implication on runoff generation in peat-covered permafrost terrain, Wat. Resour. Res., 45, W05414, doi:10.1029/2008WR006880, 2009. 